\title{
AIRASIA: FLYING CABOTAGE UNDER CLOAK IN INDONESIA AND ASEAN
}

\author{
Ridha Aditya Nugraha ${ }^{1}$
}

\begin{abstract}
Cabotage has become a sensitive issue from time to time since it is very related to the sovereignty of a state. Foreign direct investment in aviation business has lead into a new chapter of cabotage. AirAsia has seen the gap within the Indonesian Law as a way to perform a cloaked cabotage under Indonesia AirAsia. A new perspective of a cloaked cabotage under the $8^{\text {th }}$ and $9^{\text {th }}$ Freedoms of the Air held by AirAsia and Indonesia AirAsia with their successful business and marketing formula will be described.
\end{abstract}

Keywords: cabotage, airlines, cloak

\begin{abstract}
Abstrak
Cabotage telah menjadi isu sensitif dari waktu ke waktu karena sangat terkait dengan kedaulatan negara. Investasi langsung asing di bisnis penerbangan telah mengarah ke bab baru cabotage. AirAsia telah melihat celah dalam hukum Indonesia sebagai cara untuk melakukan cabotage balik jubah Indonesia AirAsia. Sebuah perspektif baru dari cabotage balik jubah Freedoms of The Air yang dipegang oleh AirAsia dan Indonesia AirAsia dengan formula bisnis dan pemasaran sukses mereka yang akan dijelaskan.
\end{abstract}

Kata kunci: cabotage, penerbangan, jubah

\section{Introduction}

Before World War II, cabotage was clearly retained as an asset of a state's power and not as an asset to be traded. ${ }^{2}$ Many states have seen cabotage as a threat to soverignty resulting no room being left for cabotage. The importance of the cabotage issue made it regulated under the Chicago Convention of 1944. Talking about cabotage means also talking about the $8^{\text {th }}$ and $9^{\text {th }}$ Freedoms of the Air under the International Air Transport Agreement

${ }^{1}$ The Author currently is studying for master degree (LL.M.) at the International Institute of Air and Space Law, Universiteit Leiden, Netherlands. The author receives a scholarship for the study from Lembaga Pengelola Dana Pendidikan (LPDP), Minsitry of Finance Republic of Indonesia and Member of German Aviaton Research Society. Alamat kontak: ridha.aditya.nugraha@gmail.com.

${ }^{2}$ Pablo Mendes de Leon, —Cabotage in Air Transport Regulationll, (Dordrecht: Martinus Nijhoff, 1992), page 17. 
of 1944 and the Most Favoured Nation clause. The connection between these provisions will be elaborated in this paper.

The rapid development in the aviation sector and the existence of foreign direct investment in the developing countries has opened a new chapter on how aviation businesses are made. AirAsia as the most prominent low cost carrier in the ASEAN region has seen this situation as an opportunity to expand its business within the member states and beyond. AirAsia has invested a huge amount in airline business through Indonesia AirAsia as it subsidiary in Indonesia. This is due to the potential in the Indonesian market due to its geographical condition and its huge population where the middle class is rising.

This paper will discuss AirAsia investment in Indonesia, especially how AirAsia sees the gap in the Indonesian Investment Law and the Indonesian Aviation Law to perform a cloaked cabotage in the country. A new perspective of a cloaked cabotage under the $8^{\text {th }}$ and $9^{\text {th }}$ Freedoms of the Air held by AirAsia and Indonesia AirAsia will be further described. At the end credit must be granted to AirAsia's successful business and marketing formula introducing low cost carrier and new _culture` in this country informasi aktual hari ini

\section{Definiton of Cabotage}

The original word of — cabotage\| is derived from a Spanish word — cabo\| which means navigation near the coast without losing sight of it. ${ }^{3}$ This term was first used in maritime navigation, especially in France, which had more than two hundred seaports open to all foreign vessels in the $16^{\text {th }}$ century. ${ }^{4}$ The situation dramatically changed when foreign vessels were banned to do cabotage based on economic background in $1791 .^{5}$

Since the beginning of the $20^{\text {th }}$ century, the term - cabotagell has been applied in the aviation sector. Many states had tried to protect their own national territory, including their colonies, by prohibiting any cabotage flight exercised by other than its nationals within each state territory due to national security and economic interest at that time. This means the maritime concept has been incorporated into air law. ${ }^{6}$ This situation has been termed - cabotage\| by scholars in reference to the former maritime situation.

Bin Cheng defined cabotage as:

${ }^{3}$ Ibid., page 1.

${ }^{4}$ Ibid., page 1.

${ }^{5}$ Ibid., page 1.

${ }^{6}$ I. H. Ph. Diederiks-Verschoor, -An Introduction to Air Lawll, (Deventer: Kluwer Law and Taxation Publishers, 1991), page 18. 
A provision that applies to air transport between any two points in the same political unit, that is to say, in the territory of a State as the term is used in air law. ${ }^{7}$

According to Nicolas M. Matte, which expressed the same principle as Bin Cheng, cabotage is about every activity that includes commercial transportation of people, goods, or mail within one country. ${ }^{8}$ These definitions, especially Bin Cheng's, are still up to date which was proven during the transfer of sovereignty over Hong Kong from the United Kingdom to the People's Republic of China on the 1 July 1997. With the transfer of sovereignty Hong Kong ceased to be within the same political unit as the United Kingdom. Due to this condition, the Hong Kong - Beijing route has become a Chinese cabotage route and Hong Kong - London route has become an international route since that date.

\section{Cabotage from Time to Time}

The Paris Conference in 1910 was the first occasion where the cabotage concept was discussed. ${ }^{9}$ After World War I, another conference on aviation was held. It was the Paris Convention of 1919 which ended up with an unequivocal proclamation of the principle of sovereignty. ${ }^{10}$ Article 16 and 17 of the Paris Convention of 1919 contained cabotage provisions which granted the contracting states to establish cabotage reservations and restrictions in connection with the carriage of persons and good, and also the right to take retaliatory measures in the case that the reservations and/or restrictions were imposed by another contracting state. ${ }^{11}$ This means these articles introduced the reciprocity concept in air law.

If World War II had shown the military importance of aviation, the period between 1919 and 1944 had equally shown the potential of civil aviation, both for economic and political purposes. ${ }^{12}$ Because of this, the

${ }^{7}$ Bin Cheng, - The Law of International Air Transportl, (London: Stevens and Sons Limited, 1962), page 314.

${ }^{8}$ Nicolas M. Matte, —Traité de Droit Aérien-Aéronautique”, (1980), page 173 as stated in supra 5, page 18-19.

${ }^{9}$ The Paris Conference ended up without any completing or signing the convention. Germany and the United Kingdom, with their own national airspace control proposal, could not accepted French proposal on the Freedom of Aerial Navigation. Also neither the military nor the economic importance of aviation had been forseen at that time. Supra note 1, page 10-11.

${ }^{10}$ The Paris Convention of 1919 was signed with a military background since the World War I had shown the military importance of aviation. Ibid., page 10.

${ }^{11}$ Ibid., page 12 . 
Chicago Convention of 1944 (-Chicago Conventionll) was held just before the end of World War II. Aviation experts gathered in the convention to formulate an updated regulation which has become the first global instrument and also one of the most important in aviation. Article 1 of the convention clarifies that each state is sovereign over its national airspace. The sovereignty of a state consists of its land area and teritorial waters, including any suzerainty, protection, or mandate of a state kabar berita pagi

Regarding cabotage, this provision is regulated under Article 7 of the Chicago Convention. The article consists of two sentences (hereinafter will be referred to as the first and second paragraphs) which are as follows:

\section{Cabotage}

Each contracting State shall have the right to refuse permission to the aircraft of other contracting States to take on in its territory passengers, mail and cargo carried for remuneration or hire and destined for another point within its territory. Each contracting State undertakes not to enter into any arrangements which specifically grant any such privilege on an exclusive basis to any other State or an airline of any other State, and not to obtain any such exclusive privilege from any other State.

Article 7 of the Chicago Convention has a broad interpretation of cabotage. Bin Cheng critisized the second paragraph of Article 7 which —any other Statell was slightly ambigous because it led into futher question whether the State is or must be a party to the Chicago Convention or not. ${ }^{13}$ This _problem' could be solved under a bilateral or unilateral agreement where national legislation will take a part since it is a very sensitive issue for the granting state, legally and economically.

The Swedish had also critisized the second paragraph of Article 7 of the Chicago Convention due to its ambiguouity. ${ }^{14}$ The ambiguouity and uncertainty concerning the granting and receiving of cabotage rights on an exclusive basis has lead to practices that states in their bilateral negotiations often refuse to include cabotage rights even if there were strong economics reason to do so. ${ }^{15}$ This ambiguity has made States very cautious before granting a cabotage right because there is not any authoritative judicial or

${ }^{12}$ Ibid., page 18 .

${ }^{13}$ Supra note 6, page 314-315.

14 The Swedish had submitted a proposal to amend Article 7 of the Chicago Convention to the $16^{\text {th }}$ Session of the ICAO Assembly in 1968 and the $18^{\text {th }}$ Session of the ICAO Assembly in 1971.

${ }^{15}$ Joseph Z. Gertler, - Towards a New Exchange of Opportunities for Airlinesll, EEC Air Transport Policy and Regulation, and Their Implications for North America: Proceedings of a Conference Held at McGill University, Montreal, Canada, September 1989 (1990), page 201. 
arbital interpretation of the second paragraph of Article 7.16 To avoid the infringement of the second paragraph, Switzerland had granted cabotage rights in a unilateral governmental permit that can be withdrawn on short notice instead of in a bilateral agreement. ${ }^{17}$ There is not any clear sanction that could be imposed on a state if such state was believed to have infringed this article. This is one of the issues that could be important in the following years in line with the rapid development of aviation and the pressure to allow the $8^{\text {th }}$ and $9^{\text {th }}$ Freedoms of the Air in the global aviation world.

In my point of view of this article, cabotage is very related with each state's sovereignty, territorial issues, and political perspectives. Cabotage rights must be positively granted before they can be exercised by foreign airlines. ${ }^{18}$ A state's permission to a foreign airline can be considered as how the state expresses its sovereignty. The state's right to refuse cabotage rights is applicable both to scheduled and non-scheduled services. ${ }^{19}$

\section{The $8^{\text {th }}$ and $9^{\text {th }}$ Freedoms of the Air}

The Five Freedoms of the Air were introduced to the world on the same date when the Chicago Convention was signed. ${ }^{20}$ The ICAO characterizes all freedoms' beyond the fifth as _so-called' because only the first five freedoms“ $\overline{\bar{h}}$ ave been officially recognized by such international treaty. ${ }^{21}$ Provisions related to cabotage are provided under the $8^{\text {th }}$ and $9^{\text {th }}$ Freedoms of the Air.

$$
8^{\text {th }} \text { Freedom of the Air: }
$$

The right to carry traffic between two points in a foreign territory, which carriage is linked with a third or fourth freedom traffic right. ${ }^{22}$

${ }^{16}$ P. P. C. Haanappel, - The Law and Policy of Air Space and Outer Spacell, (The Hague: Kluwer Law International, 2003), page 108.

${ }^{17}$ Zürich-Geneva was the domestic cabotage route in Switzerland. Ibid.

${ }^{18}$ Supra note 1 , page 22.

${ }^{19}$ Ibid.

${ }^{20}$ Supra note 6, page 314-315.

${ }^{21}<$ http://www.icao.int/Pages/freedomsAir.aspx>, as accessed in 13 May 2015.

${ }^{22}$ Supra note 1 , page 233. 
For example Garuda Indonesia, the Indonesian flag carrier, flies from Tokyo to Osaka, where both of the cities are located in Japan, and ends it journey in Jakarta as the flag carrier home base.

$9^{\text {th }}$ Freedom of the Air:

The right to carry traffic between two points in a foreign territory, which carriage is not linked with third or fourth freedom carriage. ${ }^{23}$

For example Garuda Indonesia flies from Tokyo to Osaka and vice versa where both of the cities are located in Japan.

\section{Cabotage and the Most Favoured Nation Clause}

It has been contended that Article 7 of the Chicago Convention contains a Most Favoured Nation (-MFN\|) clause. ${ }^{24}$ There are different perspectives related to this condition. Generally MFN means that if a contracting state grants cabotage rights to another contracting state, the contracting state must also grants cabotage rights to the other contracting states. Otherwise said the MFN clause does not only say that you may not give an exclusive privilege to one trading partner (the airlines of another state in this case), it also says that if you grant a privilege, all your trading partners (the airlines of the other states) will (automatically) benefit from these privileges. ${ }^{25}$

There must be a distinction related to the MFN clause under the General Agreement on Tariffs and Trade (-GATT\|) and Article 7 of the Chicago Convention because the latter talks about the MFN clause in a specific field, air law, which is not as general as GATT due to its nature. Aviation business is excluded within GATT, leaving this business with a previlege. This standpoint leads us to an idea that third states cannot automatically derive the same cabotage rights from such a deal. ${ }^{26}$ Automatic extension of these privileges to third states or of privileges that have been exchanged between granting and receiving state would be the way how the MFN clause is implemented. ${ }^{27}$ This

${ }^{23}$ Ibid.

${ }^{24}$ Pablo Mendes de Leon, -Euro Cabotage: A Lever for Liberalization of International Civil Aviation\|, EEC Air Transport Policy and Regulation, and Their Implications for North America: Proceedings of a Conference Held at McGill University, Montreal, Canada, September 1989 (1990), page 196.

$$
\begin{aligned}
& { }^{25} \text { Ibid., page } 197 . \\
& { }^{26} \text { Ibid., page } 197 . \\
& { }^{27} \text { Ibid., page } 197 .
\end{aligned}
$$


condition has lead us to a conclusion thatthe scope of the MFN clause in air law is more limited compared to other commercial laws. ${ }^{28}$

\section{Indonesia AirAsia: A Cloaked Cabotage in Indonesia}

This part will discuss the recent development related to cabotage in Indonesia and the existence of AirAsia Group and Indonesia AirAsia. It is very interesting to see how AirAsia interpretes the Indonesian laws to establish its domestic and international air transportation business in Indonesia, as also happens in Thailand.

\section{AirAsia Group and Indonesia AirAsia}

AirAsia Berhad (-AirAsiall) is a Malaysian low-cost carrier headquartered in Kuala Lumpur and nowadays has become the holding company of all AirAsia brands in the world. AirAsia was established in 1994 and began its domestic operation in 1996. After the take over by Tony Fernandes via its Tune Air Sdn Bhd in 2001, the airline launched its first international flight to Bangkok in 2003 and was followed to destinations in the neighbouring countries, including Indonesia. ${ }^{29}$

AirAsia existence in Indonesia was started when an Indonesian airline was established under the name of Air Wagon International (known as Awair) in 1999. Awair started operating domestically within Indonesia as an associate of AirAsia in 2004 and changed its name into Indonesia AirAsia in 2005.30 Today the airline is considered as the leading low cost carrier in Indonesia.

\section{The National Law of Indonesia regarding Cabotage}

Article 84 and 85 of Law No. 1 Year 2009 regarding Aviation (-Indonesian Aviation Lawll) as the positive law clearly stated that unscheduled and scheduled domestic air transportation can only be held by an Indonesian national company. Not even a single foreign company is given a chance to held the transportation in Indonesia. These articles express that cabotage is prohibited in Indonesia under the Indonesian Aviation Law. Futhermore the cabotage prohibition expresses the sovereignty of Indonesia to regulate its airspace which is derived from Article 1 of the Chicago Convention.

${ }^{28}$ Ibid., page 197.

${ }^{29}<$ http://en.wikipedia.org/wiki/AirAsia\#History>, as accessed in 13 May 2015.

${ }^{30}$ This chage of name was in line with the other AirAsia branded airlines in the region at that time, <http://en.wikipedia.org/wiki/Indonesia_AirAsia\#History>, as accessed in 13 May 2015. 
The Indonesian Aviation Law does not stand alone since the Law No. 25 Year 2007 regarding Capital Investment (-Indonesian Investment Lawll) and Law No. 40 Year 2007 regarding Limited Company (-Indonesian Company Lawll) are also in force. The Indonesian Investment Law has opened an opportunity for foreign company or individual to establish a direct investment in Indonesia. The established foreign investment company itself will be in form of an Indonesian limited company with minimum two shareholders which is regulated under the Indonesian Company Law. According to the Negative Investment List ${ }^{31}$ which comes under the Indonesian Investment Law, a foreign company could only own maximum 49\% shares in an Indonesian limited company which operates domestic air transportation, thus protecting the Indonesian shareholder(s) with at least a single majority. The purpose of having this single majority provision is to fill the _gap“ which is not regulated under the previous law. ${ }^{3233}$ This provision also contains a non-discrimination principle by being applicable generally to all foreign investors without any nationality exception.

AirAsia, as a Malaysian public listed company which means a foreign company in the Indonesian perspective, has seen this provision as a way to own $48.9 \%^{34}$ of PT. Indonesia AirAsia (-Indonesia AirAsiall) shares through its wholly-owned subsidiary, AirAsia Investment Ltd.. The remaining $51.1 \% 35$ is owned by PT. Fersindo Nusaperkasa, an Indonesian company, to guarantee that the majority and _control' are still in the Indonesian hands. By having this kind of structure, AirAsia existence in Indonesia through its share ownership mathematically does not infringe any of the Indonesian Aviation Law, the Indonesian Investment Law, nor the Indonesian Company Law.

Indonesia AirAsia organizational structure is as follow:

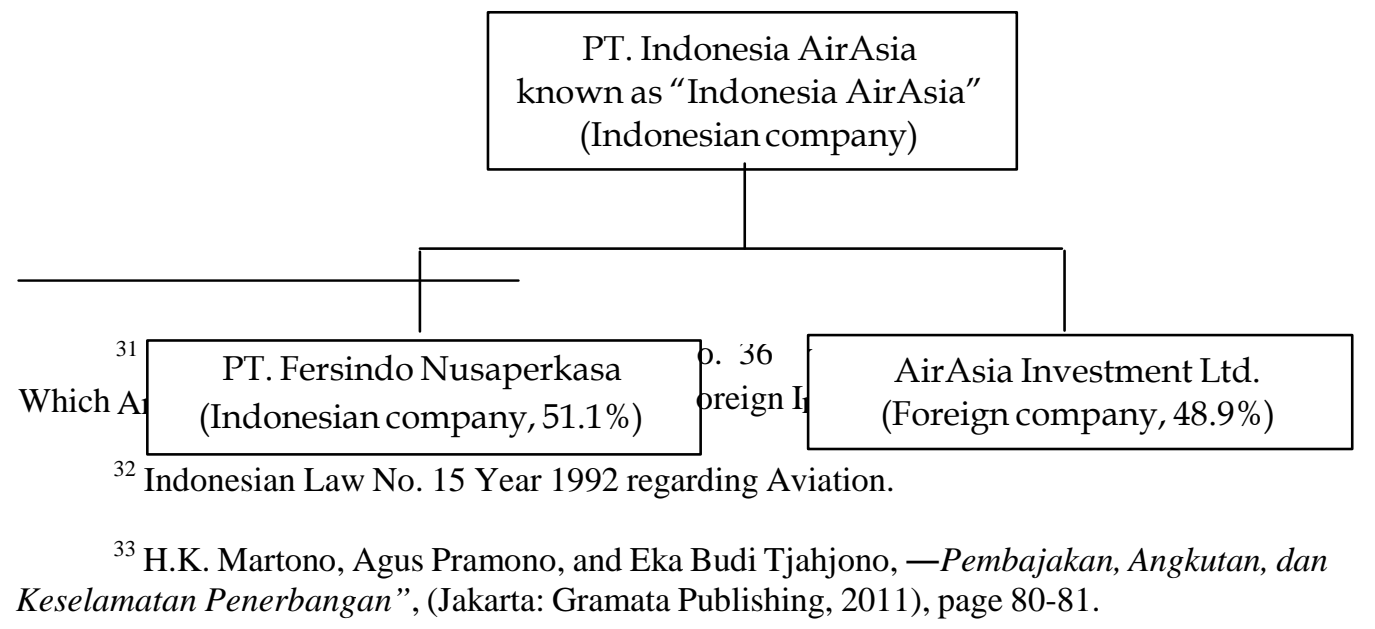

$34 \quad<$ http://www.airasia.com/my/en/about-us/ir-organizational-structure.page>, as accessed in 13 May 2015.

$35<$ http://en.wikipedia.org/wiki/Indonesia_AirAsia>, as accessed in 13 May 2015. 


\section{Indonesia AirAsia and Cabotage in Indonesia}

This paper would criticize the single majority concept under the Indonesian Investment Law and the Indonesian Aviation Law related to AirAsia foreign direct investment in Indonesia. First of all, this concept must be appreciated since the purpose is to protect the national shareholder(s) by having control in the company. Moreover it will also protect the airline company from loosing its national identity.

The _classic' problem in this concept will be the government supervision towards its implementation or law enforcement. Even though an affiliation between the foreign company and the Indonesian company in the established company is not allowed, the government has difficulty to trace it down. If we take a look at the structure of Indonesia AirAsia, the question arisen will be how could the government know if the shareholder(s) of PT. Fersindo Nusaperkasa has not come into any affiliation with AirAsia or its wholly-owned subsidiary, AirAsia Investment Limited, if such affiliation agreement were made outside the territory of Indonesia. An appointment of nominee(s) (which exist under the British Virgin Island Law) has already become a phenomenon in Indonesia and this condition could be very likely implemented. It could end up with the chance of AirAsia to have more than $49 \%$ shares, or even up to $100 \%$ shares, in Indonesia AirAsia under the cloak of a nominee agreement. If this condition happens, AirAsia has been doing a cabotage in Indonesia through and under the cloack of its subsidiary company, Indonesia AirAsia, by infringing the Indonesian Investment Law and the Indonesian Aviation Law.

Another legal issue that will arise from Indonesia AirAsia is about the national control based on the single majority concept which is stipulated under the Indonesian Investment Law and the Indonesian Aviation Law. A comment on the weakness of this concept must be addressed where it is only stated that the Indonesian nationals, could be either a person or company, shall own minimum 51\% shares in the airline company. There is not any further provision regarding the holding of this company whether the holding could establish an affiliation with the foreign company or not. The positive law could lead into a situation where the 'scattered Indonesian shareholders, each with their own interest, are facing' the well-organized and well-capitalized foreign company. If this condition prevails, the applicable single majority concept to protect Indonesian nationals will be useless. The Italian flag carrier, Alitalia, also faces the same condition when the United Arab Emirates flag carrier, Etihad Airways, bought $49 \%{ }^{36}$ of it shares in 2014.

\footnotetext{
${ }^{36}<$ http://www.thenational.ae/business/aviation/etihad-codeshare-with-alitalia-to-boostconnectivity-to-italian-cities-from-next-year>, as accessed in 13 May 2015.
} 
In relation with the enforcement of the single majority concept, the main question in this case will be how could the government make sure that PT. Fersindo Nusaperkasa, not AirAsia, has the control if they could not guarantee PT. Fersindo Nusaperkasa to _secure“ its single majority position in Indonesia AirAsia due to weak supervision and law enforcement. Ensuring effective control ${ }^{37}$ within Indonesian hands is something that could not be answered mathematically like the majority ownership issue. This condition will strengthen the premise that AirAsia has been doing a cabotage in Indonesia through and under the cloack of Indonesia AirAsia. Thus under this cloaked cabotage perspective, flight from Jakarta to Bali vice versa with Indonesia AirAsia could be considered as a cloaked $9^{\text {th }}$ Freedom of the Air under AirAsia flag (precisely as a Malaysian carrier) rather than a domestic flight.

\section{The Similarity Between Indonesia AirAsia and Thai AirAsia}

There is a similarity between the Indonesian and Thailand governments' perspective towards its aviation policy. Both of the countries allow a limited foreign investment in the aviation sector which is no more than $49 \%^{38}$. Both Indonesian and Thailand laws have a single majority concept to protect the national airline(s). AirAsia has seen this condition as a way to get into Thailand market by owning $45 \%{ }^{39}$ of Thai AirAsia Co. Ltd. (-Thai AirAsiall) through AirAsia Investment Ltd.. This is the same structure how AirAsia penetrates in Indonesia. The remaining shares in Thai AirAsia is owned by Asia Aviation Public Co. Ltd., a Thailand company. ${ }^{40}$ This company used the proceeds from the Initial Public Offering (IPO) to subscribe the newly issued shares of Thai AirAsia, which increased its shareholding to a current of $55 \%$ in Thai AirAsia. ${ }^{41}$

${ }^{37}$ The European Union (EU) provides an explicit definiton of effective control. Article 2(g) of Regulation (EC) No. 2407/92 defines effective control as —a relationship constituted by rights, contracts, or any other means which, either separately or jointly and having regard to the considerations of fact or law involved, confer the possibility of directly or indirectly exercising a decisive influence on an undertaking, in particular by: (a) the right to use all or part of the assets of an undertaking; (b) rights or contracts which confer a decisive influence on the composition, voting or decisions of the bodies of an undertaking or otherwise confer a decisive influence on the running of the business of the undertaking.\|

${ }^{38}$ Indonesian Law No. 25 Year 2007 regarding Capital Investment and Thailand Act Year 1954 regarding Air Navigation.

39 <http://www.airasia.com/my/en/about-us/ir-organizational-structure.page>, as accessed in 13 May 2015.

$40<$ http://www.aavplc.com/index.html?menu=aav_background\&lang=en>, as accessed in 13 May 2015. 
AirAsia current organizational structure in Indonesia and Thailand is as follows:

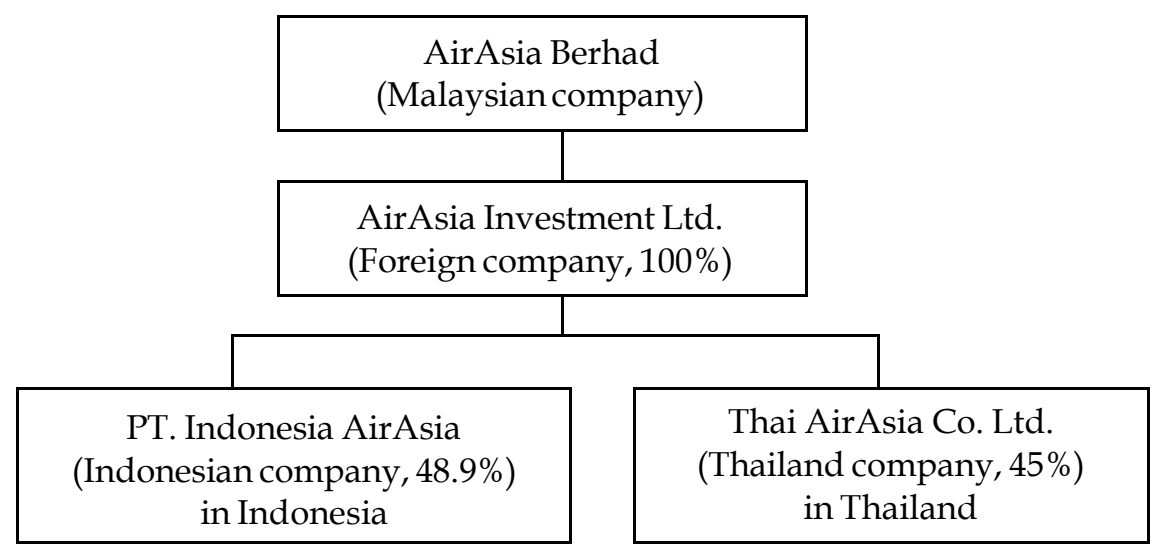

The similarity of the aviation policy, investment condition, and structure between Indonesia and Thailand will lead into another cloaked cabotage in Thailand. A simplification could be made that the flight from Bangkok to Phuket vice versa with Thai AirAsia is in the same condition as the flight from Jakarta to Bali vice versa with Indonesia AirAsia, which could be considered as a cloaked $9^{\text {th }}$ Freedom of the Air under AirAsia flag (precisely as a Malaysian carrier) rather than a domestic flight.

\section{AirAsia: Flying the Cloaked $8^{\text {th }}$ and $9^{\text {th }}$ Freedoms of the Air}

AirAsia has been flying within the ASEAN countries, establishing its headquarter in Malaysia and its subsidiaries in Indonesia, Thailand, and the Philippines. By establishing the subsidiaries in these strategic countries, AirAsia has an advantage to pull all the strings from the ASEAN market. On the other side, the well established company in the ASEAN provides AirAsia an =opportunity to fly the $8^{\text {th }}$ and $9^{\text {th }}$ Freedoms of the Air under cloak. AirAsia is _suspected' flying both these freedoms in Indonesia and Thailand at the same time.

AirAsia has given the information of all its flight destinations, including its subsidiaries, in one single webpage ${ }^{42}$ clearly. The website 
also provides an option to book a multi-city trip which is rarely provided in the official airline website, and for sure it is not provided in other lowcost carrier websites such as EasyJet, ${ }^{43}$ Ryanair, ${ }^{44}$ and Wizz Air. ${ }^{45}$ The complete information of flight destinations and multi-city trip options in AirAsia's website provides an advantage for the passenger to book the ticket which system automatically shows all the connecting flights (if needed) with AirAsia subsidiaries in a single transaction. The purpose of this system is no other than to avoid cabotage restriction in each national laws of AirAsia's subsidiaries.

If a passenger from Surabaya, which airport mostly serves Indonesian domestic routes only, wants to fly to Chiang Mai, the passenger will have two options. First, the passenger could book directly Surabaya - Chiang Mai ticket via AirAsia system to provide the schedule with limited option(s). The second option is the passenger could book a Surabaya-Jakarta ticket with Indonesia AirAsia and a Jakarta-Chiang Mai ticket with transit in Bangkok in order to get a more flexible schedule. The passenger will change from Indonesia AirAsia to Thai AirAsia in Bangkok in order to continue the flight to Chiang Mai. Whatever the passenger's decision is, two stopovers will be made in Soekarno-Hatta International Airport, Jakarta, and Don Muang International Airport, Bangkok. The existence of the two stopovers is essential to determine whether the airline performs cabotage or not.

Stopover is defined as a break of the journey arranged at the passenger's request, for reasons other than making an aircraft connection. ${ }^{46}$ Another stopover definition is a deliberate interruption of a journey by a passenger, agreed to in advance by the carrier, at a point between the place of departure and the place of destination. ${ }^{47}$ It seems AirAsia is trying hard to outwit it.

These two transits whether under a single ticket or multiple tickets seems are made under the passenger's own intention. However this condition comes as a result from AirAsia's capability to provide such information on its website so the passenger could have many options to book the ticket easily according to each passenger's schedule. Furthermore with an assumption that AirAsia (precisely as a Malaysian carrier based in Kuala Lumpur) has the effective control in Indonesia AirAsia and Thai AirAsia, this condition has made an option to arrange

\footnotetext{
${ }^{42}<$ http://www.airasia.com/ot/en/home.page?cid=1>, as accessed in 14 May 2015.

${ }^{43}<$ http://www.easyjet.com/en>, as accessed in 14 May 2015.

${ }^{44}<$ http://www.ryanair.com/>, as accessed in 14 May 2015.

${ }^{45}<$ http://wizzair.com/en-GB/Search>, as accessed in 14 May 2015.

${ }^{46}$ Supra note 1, page 33.

${ }^{47}$ Supra note 6, page 324.
} 
the best _transit' schedule in Soekarno-Hatta International Airport and Don Muang International Airport possible between the two airlines.

These are the recent schedules from Surabaya to Chiang Mai via Jakarta and Bangkok with Indonesia AirAsia and Thai AirAsia:48

\begin{tabular}{|c|c|c|c|}
\hline Destination & Flight 1 & Flight 2 & Flight 3 \\
\hline \multicolumn{4}{|c|}{$1^{\text {st }}$ option, on the same day } \\
\hline Surabaya - Jakarta & $05.55-07.15$ & & \\
\hline Surabaya - Jakarta & $08.00-09.20$ & & \\
\hline Surabaya - Jakarta & $09.20-10.40$ & & \\
\hline Surabaya - Jakarta & $12.45-14.05$ & & \\
\hline Jakarta - Bangkok & & $16.45-20.15$ & \\
\hline Bangkok - Chiang Mai & & & $\begin{array}{c}20.35- \\
21.50\end{array}$ \\
\hline Bangkok - Chiang Mai & & & $\begin{array}{c}21.25- \\
22.35\end{array}$ \\
\hline \multicolumn{4}{|c|}{$2^{\text {nd }}$ option, with an overstay in Jakarta } \\
\hline Surabaya - Jakarta & $17.25-18.45$ & & \\
\hline Surabaya - Jakarta & $20.50-22.10$ & & \\
\hline Jakarta - Bangkok & & $07.20-10.45$ & \\
\hline Bangkok - Chiang Mai & & & $\begin{array}{c}11.35- \\
12.55\end{array}$ \\
\hline Bangkok - Chiang Mai & & & $\begin{array}{c}12.25- \\
13.45\end{array}$ \\
\hline Bangkok - Chiang Mai & & & $\begin{array}{c}13.45- \\
15.00\end{array}$ \\
\hline Bangkok - Chiang Mai & & & $\begin{array}{c}15.45- \\
17.00\end{array}$ \\
\hline Bangkok - Chiang Mai & & & $\begin{array}{c}16.55- \\
18.10\end{array}$ \\
\hline Bangkok - Chiang Mai & & & $\begin{array}{c}19.20- \\
20.45\end{array}$ \\
\hline
\end{tabular}

The passenger is more likely doing a transit rather than a stopover with its own intention in Jakarta and Bangkok. The transits are just a cloak to hide the purpose of doing a cabotage in order to make a

$48<$ http://booking.airasia.com/Select.aspx>, as accessed in 14 May 2015. 
complete journey with the airlines. This condition is very similar with TAP Portugal _stop-over strategy which used to operate AmsterdamLisbon-Willemstad route. ${ }^{49}$ The passengers stayed in Lisbon for a night where the airline paid for the hotel and special travel coupons were offered to them in order to attract the passengers who were willing to travel the city with their own intention to meet the requirement of a stopover. 50

Believing it is the Malaysian nationals behind AirAsia who has the effective control in Indonesia AirAsia and Thai AirAsia, including to arrange such transit schedules between these airlines, the existence of Indonesia AirAsia and Thai AirAsia are merely just another name of (the Malaysian) AirAsia itself. This means AirAsia is flying the $8^{\text {th }}$ and $9^{\text {th }}$ Freedoms of the Air in the Surabaya-Chiang Mai route. The flight from Surabaya to Jakarta and from Bangkok to Chiang Mai could be considered as a cloaked $8^{\text {th }}$ Freedom of the Air. Then the flight from Surabaya-Jakarta-Bangkok or Jakarta-Bangkok-Chiang Mai could be seen as a cloaked $9^{\text {th }}$ Freedom of the Air from Thai AirAsia's perspective.

\section{Behind AirAsia's Success Story: Branding and New Culture}

There is a sentimental feeling for some Indonesians when talking about Malaysia due to the history between these two countries. ${ }^{51}$ As today such rivalry does still exist in daily life and also influences the commercial world. Speaking of aviation business, some Indonesians are quite reluctant to fly with Malaysia Airlines (as the Malaysian flag carrier) due to its nationality. A short conclusion could be drawn in general there has been a negative sentiment towards Malaysian business among the Indonesians.

It is interesting to see how AirAsia overcomes this nationality issue in terms of branding through its subsidiaries. The airline comes without any Malaysian nationality identification neither from its name, colour, or sign. They even put _Indonesia' alongside _AirAsia' to have an _Indonesia AirAsia“ in order to strengthen their brand as an Indonesian and not a Malaysian airline. To make the airline more _transparant' and also _neutral' in terms of nationality, AirAsia is considering an Initial Public Offering (IPO) for Indonesia AirAsia. ${ }^{52}$ As a result in 2013 the airline successfully grabbed 4\% of

\footnotetext{
${ }^{49}$ Supra note 1 , page 33.

${ }^{50}$ Ibid.

${ }^{51}<$ http://indonesiaindonesia.com/f/58118-asal-muasal-konflik-indonesia-malaysia/>, as accessed in 14 May 2015.

52 <http://www.bloomberg.com/news/articles/2015-03-12/airasia-considering-ipo-forindonesia-unit-undeterred-by-crash>, as accessed in 15 May 2015.
} 
the Indonesian domestic market share for passengers, ranked at the $6^{\text {th }}$ and leading above Merpati Nusantara ${ }^{53}$ as the other Indonesian flag carrier besides Garuda Indonesia. ${ }^{54}$ Furthermore with this successful business plan outwitting today's nationality restrictions within numerous ASEAN countries, AirAsia as a low-cost carrier could become the first Pan-ASEAN airline. ${ }^{55}$ No doubt AirAsia is in an advantagous position to gain from ASEAN Open Skies. ${ }^{56}$

Most low-cost carriers tend to focus on secondary airports which charge less for landing and terminal fees. ${ }^{57}$ Faster turn times and more efficient use of staff and aircraft are also the main consideration for using secondary airports. ${ }^{58}$ This case does not happen with Indonesia AirAsia where they are flying from the primary Soekarno-Hatta International Airport, branding them with prestige as a =major ${ }^{\star}$ airline and equals with the other flag carriers, leaving Citilink Indonesia ${ }^{59}$ as their main competitior behind. Operating with only one type of aircraft, Airbus A320-200, the airline could reduce its operating and crew training costs.

Innovation is the key for AirAsia's success story where the airline becomes the first in Asia to introduce internet booking with online payments and ticketless travel. ${ }^{60}$ This was a new phenomenon in $2003^{61}$, especially in Indonesia where usually people book airline tickets via travel agent. The

${ }^{53}$ Merpati Nusantara is an Indonesian flag carrier which was established to serve domestic and pioneer flights in 1962. Originally the airline was not set for international flights. <http://www.merpati-air.net/>, as accessed in 15 May 2015.

54 Organization for Economic Co-operation and Development Report No. DAF/COMP/WD(2014)70 dated 28 May 2014 as presented in the $121^{\text {st }}$ meeting of OCED Competition Committee on 19 June 2014, page 6.

${ }^{55}$ Alan Khee-Jin Tan, - The 2010 ASEAN-China Air Transport Agreement: Placing the Cart before the Horse?\|, Air and Space Law, Volume 37 No. 1 (2012), page 48.

56 Siew Yean Tham, -ASEAN Open Skies and the Implications for Airport Development Strategy in Malaysiall, Asian Development Bank Institute Working Paper No. 119, (Tokyo: Asian Development Bank Institute, 2008), page 18.

${ }^{57}$ David Gillen and William G. Morrison, -Regulation, Competition, and Network Evolution in Aviation\|, Journal of Air Transport Management, Volume 11 (2005), page 165.

${ }^{58}$ Ibid.

${ }^{59}$ Citilink Indonesia only fly from Halim Perdanakusuma Airport. It is a secondary airport in Jakarta, much smaller compared with Soekarno-Hatta International Airport. See <http://www.flightradar24.com/data/airports/HLP>, as accessed in 15 May 2015.

${ }^{60}$ John F. O‘Connell and George Williams, -Passengers` Perceptions of Low Cost Airlines and Full Service Carriers: A Case Study Involving Ryanair, Aer Lingus, AirAsia, and Malaysia Airlines\|, Journal of Air Transport Management, Volume 11 (2005), page 266.

${ }^{61}$ Ibid. 
absence of Information and Technology (IT) law in Indonesia at that time did not become an obstacle for this new phenomenon due to lower ticket price offered with direct bookings. In the early days AirAsia was boycotted by travel agents since the airline sought to circumvent them with its = $\mathrm{B} 2 \mathrm{C}^{\text {' }}$ (Business to Consumer) approach. ${ }^{62}$ Speaking of checked baggage, the airline successfully introduced a new _culture' where passengers only pay if they have any. This culture currently becomes a _normal' thing within current aviation business. Indonesia AirAsia co-branding with CIMB Niaga Bank ${ }^{63}$ is also another smart move to attract more passengers. Under _CIMB Niaga AirAsia Savers ${ }^{64}$ and =Big Point ${ }^{`} 65$ programs, customers could earn cash back and redeem points for purchasing AirAsia tickets. The customers could also get the most updated promotions of heavily discounted promotional fares which are designed to promote the airline through =word-of-mouth'.66 Interesting to see how these =Malaysian' companies work together to grab their own market.

At the end although low-cost carriers are relatively new to Asia, AirAsia has already developed very strong low fare brands through strong advertising and clever use of media. ${ }^{67}$ As of today _Now everyone can fly‘ has become a successful marketing icon in ASEAN. 68

\section{The Future of Cabotage in Indonesia and ASEAN: The Long and Winding Road}

Having seen the AirAsia cloaked cabotage in Indonesia and with the insolvency of Merpati Nusantara in 2014 which serves remote routes, it will lead to a pressure towards the Indonesian government to allow cabotage. Today the routes between small or remote islands are temporarlly abandonded, leaving the national economy and integration in danger. These abandonded

\footnotetext{
${ }^{62}$ Peter Waring and Teresa Shuk-Ching Poon, - The Lowest of Low-Cost Carriers: The Case of AirAsiall, The International Journal of Human Resource Management, Volume 21 No. 2 (2010), page 203.

${ }^{63}$ CIMB Niaga Bank is an Indonesian bank with a Malaysian entity as one of the most influenced shareholders behind it. As today they have become the $5^{\text {th }}$ biggest bank in Indonesia. <https://www.cimbniaga.com/index.php?ch=gen_about\&pg=gen_about_us\&ac= 2\&tpt=niaga $>$, as accessed in 15 May 2015.

$64<$ https://www.cimbniaga.com/?ch=cn_p_db\&pg=cn_p_db_sav\&ac=11>, as accessed in 15 May 2015.

${ }^{65}$ Ibid.

${ }^{66}$ Supra note 60, page 206.

${ }^{67}$ Supra note 58, page 268.

${ }^{68}$ Supra note 60, page 206.
} 
routes are not easy to be replaced since financing new aircraft(s) needs time and a huge amount of money. There is an urgency to solve this problem and waiting for years for new aircrafts will be too late. Meanwhile the well planned and structured AirAsia's foreign direct investment through Indonesia AirAsia combined with the gap'69 in the Indonesian Aviation Law and Indonesian Investment Law has made the government lose _half" of its sovereignty.

If the government is not ready to allow a full' cabotage, they could learn from the Swiss cabotage which was restricted only for Zürich-Geneva ${ }^{70}$ route. This means the government could give their conditions which routes are open for cabotage in order to solve the problem under an unilateral agreement. An unilateral agreement is important since Article 7 of the Chicago Convention contains the _limited' MFN clause. It is better not to put cabotage rights under a bilateral agreement to avoid being interpreted as a discrimination toward the others. Thus the $8^{\text {th }}$ Freedom of the Air is more likely to be allowed by the Indonesian government since it is not completely flying only through Indonesian airspace like the $9^{\text {th }}$ Freedom of the Air and also to avoid the country losing face.

The recent development in ASEAN with its single aviation market in 2015 will lead into an air travel integration between the member states, including Indonesia which has the biggest potential market. The $8^{\text {th }}$ and/or $9^{\text {th }}$ Freedom(s) of the Air will be allowed in the future as the next step of the open sky policy in ASEAN and it is just a matter of time. With this forecast, the Indonesian government should prepare its best to face it rather than building a giant wall toward these Freedoms of the Air. This condition could be a benefit if the government could prepare a strategy to expand its national airlines in the ASEAN countries when the time comes. There is a possibility in the following years Garuda Indonesia will be allowed to serve Bali-Phuket-Bangkok route, concentrating on regional route which is more profitable, and Thai Airways will also be granted the permission to serve Bangkok-Jakarta-Bali route. In order to successfully grab the market, Garuda Indonesia should learn humbly from AirAsia. Having Citilink Indonesia ${ }^{71}$ as its subsidiary in the low-cost

${ }^{69}$ The provision to welcome foreign investment in aviation business up to $49 \%$ in Indonesia is too liberal with the condition that cabotage is prohibited in Indonesia. Indonesia and Thailand share the same percentage as in the European Union (EU) which allows cabotage between the Member States based on EU Regulation No. 1008/2008. The condition in the Philippines which restricted foreign ownership in its airlines with at least $60 \%$ of the ownership resides in local hands could be considered as the ideal condition to be implemented in Indonesia which prohibit cabotage. An additional clause regarding effective control which shall reside in local hands must be well considered by the government. See Alan Khee-Jin Tan, -Aviation Policy in the Philippines and the Impact of the Proposed Southeast Asian Single Aviation Marketll, Air and Space Law, Volume 34 No. 4/5 (2009), page 286.

\footnotetext{
${ }^{70}$ Supra note 1 , page 59.

${ }^{71}$ Citilink Indonesia is an Indonesian low-cost carrier and a subsidiary company of the flag carrier, Garuda Indonesia. The airline was established in 2009. <https://www.citilink.co.id/company-profile>, as accessed in 14 May 2015.
} 
carrier segment (operating the same type of aircraft ${ }^{72}$ as AirAsia), this is a good starting point where apple to apple comparison could be made.

The rapid expansion of low-cost carriers in Indonesia and ASEAN will lead into a possibility of a cooperation between a flag carrier and a low-cost carrier with the same nationality due to a more competitive market in the future. Probably it has not become an issue today where cooperation between airlines are still between full service or flag carriers under the three biggest airline alliances which are Oneworld, SkyTeam, and Star Alliance. ${ }^{73}$

\section{Concluding Remarks}

Cabotage is a sensitive issue since it is very related to the sovereignty of a state and must be interpreted with the principle of good faith. AirAsia through Indonesia AirAsia has been flying cabotage under cloak through the gap in the Indonesian laws while the government is made helpless'. This situation describes the development of aviation business which has lead into a pressure to allow the $8^{\text {th }}$ and/or $9^{\text {th }}$ Freedom(s) of the Air. It is better for the Indonesian government to allow a conditional cabotage under unilateral agreement(s), just like the Swiss did, rather than _losing' its sovereignty through AirAsia's well planned corporate structure. The cloaked cabotage held by AirAsia in Indonesia and ASEAN must be seen as AirAsia corporate policy which is purely commercial.

The implementation of the $8^{\text {th }}$ and/or $9^{\text {th }}$ Freedom(s) of the Air in Indonesia as a part of ASEAN is just a matter of time. AirAsia is in an advantagous position to become the first Pan-ASEAN airline through its =revolutionary ${ }^{\prime}$ business strategy in this region. No doubt AirAsia has successfully established a strong branding with its _Now everyone can fly slogan.

${ }^{72}<$ https://www.citilink.co.id/fleet>, as accessed in 14 May 2015.

${ }^{73}$ Stephen W. Wang, —Do Global Airline Alliances Influence the Passenger`s Purchase Decision?\|, Journal of Air Transport Management, No. 37 (2014), page 54. 


\section{Bibliography}

\section{Books}

Bin Cheng. The Law of International Air Transport. London: Stevens and Sons Limited, 1962.

Diederiks-Verschoor, I. H. Ph.. An Introduction to Air Law. Deventer: Kluwer Law and Taxation Publishers, 1991.

de Leon, Pablo Mendes. Cabotage in Air Transport Regulation. Dordrecht: Martinus Nijhoff, 1992.

Haanappel, P. P. C.. The Law and Policy of Air and Space and Outer Space. The Hague: Kluwer Law International, 2003.

Martono, H.K.; Pramono, Agus; and Tjahjono, Eka Budi. Pembajakan, Angkutan, dan Keselamatan Penerbangan, 2011.

\section{International Convention}

International Civil Aviation Organization (ICAO). Convention on International Civil Aviation. The Chicago Convention on 7 December 1944.

\section{National Laws}

Indonesia. Law regarding Aviation. Law No. 1 Year 2009.

Indonesia. Law regarding Aviation. Law No. 15 Year 1992.

Indonesia. Law regarding Capital Investment. Law No. 25 Year 2007.

Indonesia. Law regarding Limited Company. Law No. 40 Year 2007.

Indonesia. Presidential Regulation regarding List of Business Which Are Closed and Conditionally Open for Foreign Investment. Presidential Regulation No. 36 Year 2010.

Thailand. Air Navigation Act. Act Year 1954.

\section{Regional Laws}

European Economic Community. Regulation on Licensing of Air Carriers. Regulation (EEC) No. 2407 Year 1992.

European Union. Regulation on Common Rules for the Operation of Air Services in the Community. Regulation (EC) No. 1008 Year 2008. 


\section{Articles}

Alan Khee-Jin Tan. - Aviation Policy in the Philippines and the Impact of the Proposed Southeast Asian Single Aviation Marketll. Air and Space Law Volume 34 No. 4/5, 2009.

Alan Khee-Jin Tan. - The 2010 ASEAN-China Air Transport Agreement: Placing the Cart before the Horse?\|. Air and Space Law Volume 37 No. $1,2012$.

de Leon, Pablo Mendes. -Euro Cabotage: A Lever for Liberalization of International Civil Aviationl. EEC Air Transport Policy and Regulation, and Their Implications for North America: Proceedings of a Conference Held at McGill University, Montreal, Canada, September 1989, 1990.

Gertler, Joseph Z.. - Towards a New Exchange of Opportunities for Airlinesll. EEC Air Transport Policy and Regulation, and Their Implications for North America: Proceedings of a Conference Held at McGill University, Montreal, Canada, September 1989, 1990.

Gillen, David and Morrisson, William G.. - Regulation, Competition, and Network Evolution in Aviationll. Journal of Air Transport Management Volume 11, 2005.

O`Connell, John F. and Williams, George. -Passengers` Perceptions of Low Cost Airlines and Full Service Carriers: A Case Study Involving Ryanair, Aer Lingus, AirAsia, and Malaysia Airlines\|. Journal of Air Transport Management Volume 11, 2005.

W. Wang, Stephen. - Do Global Airline Alliances Influence the Passenger's Purchase Decision?\|. Journal of Air Transport Management No. 37, 2014.

Waring, Peter and Teresa Shuk-Ching Poon. - The Lowest of Low-Cost Carriers: The Case of AirAsiall. The International Journal of Human Resource Management Volume 21 No. 2, 2010.

\section{Websites}

<http://booking.airasia.com/Select.aspx>, in 14 May 2015.

$<$ http://en.wikipedia.org/wiki/AirAsia\#History>, accessed in 13 May 2015.

<http://en.wikipedia.org/wiki/Indonesia_AirAsia>, accessed in 13 May 2015.

$<$ http://en.wikipedia.org/wiki/Indonesia_AirAsia\#History>, accessed in 13 May 2015.

$<$ http://indonesiaindonesia.com/f/58118-asal-muasal-konflik-indonesiamalaysia/>, accessed in 14 May 2015.

$<$ http://wizzair.com/en-GB/Search>, accessed in 14 May 2015.

Regional, H. (n.d.). Warta Berita terkini dan terbaru hari ini.

Retrieved July 22, 2017, from http://www.harianregional.com/ 